- Jalu Lintang Y.A

Universitas Gadjah Mada

\title{
Pencinta Alam Sebagai Bentuk Peran Pemuda Di Tengah Tantangan Kehidupan Kota
}

\begin{abstract}
A B S T R A C T
The important role of youth as an agent of change in the society is questioned. Seeing the modern society that has new challenge which is the capitalist society culture impacts in alienation. The capitalist culture that occurs in urban society is considered as a change that gives impact at youth role and it becomes the dominant culture. Seeing this phenomena, this article will answer how youth do the counter culture toward the dominant culture. This dominant culture is seen as a culture that can alienate the youth from their surrounding and this will weaken the youth role in society. Counter culture is defined as a culture that can counter the dominant culture in the society. While alienantion is defined as someone's clutter from certain thing that alienates him or her from himself or herself, others, or the surrounding where she or he lives like in fromm concept. This article will present the life pattern of nature lovers. This article will begin by describing the life of nature lovers from how it is formed, the daily life of nature lovers and their value or view as a form counter culture toward the dominant culture which is the capitalist culture that alienates youth from their environment. This article is written based on descriptive analysis of interview, observation, and literature review in nature lovers organisation in university level which is often called Mapala.
\end{abstract}

Keywords: nature lovers, alienation, counter culture

\section{PENDAHULUAN}

Peristiwa besar bangsa kita seperti hari kebangkitan nasional, sumpah pemuda, proklamasi kemerdekaan, pergantian rezim Soekarno dan Soeharto menunjukan peran besar pemuda. Berkaca dari peristiwa besar tersebut stigma pemuda sebagai agen perubahan pun muncul di masyarakat umum. Seiring berjalannya waktu banyak terjadi perubahan sosial di masyarakat, salah satu sebabnya adalah modernisasi pada masyarakat. Kota sebagai pusat modernisasi membuat orang berbondong-bondong datang kesana. Perkembangan masyarakat kota semakin besar, tidak terkecuali generasi muda kota yang menjadi bagiannya. Prediksi dari BPS pada tahun 2035 66,6\% masyarakat Indonesia akan tinggal di kota. Dari $66,6 \%$ tersebut $51 \%$ nya adalah penduduk kalangan anak muda. Tentu dengan latar seperti itu akan ada pengaruh dan perubahan pada kehidupan pemuda. Beberapa orang kemudian mulai mempertanyakan apakah dengan kehidupan perkotaan yang cenderung mengarah pada budaya konsumi ini akan berdampak pada pemuda, akankah pemuda masih dapat melakukan perannya sebagai agen perubahan?

Deskripsi tentang kota dapat dilihat dengan ciri ekonomi yang 


\begin{abstract}
bertumpu pada sektor industri hubungan antar orang. Aktivitas (sekunder) dan sektor jasa (tersier), sedang secara sosial jumlah penduduknya besar dengan susunan penduduk yang heterogen dan wilayahnya padat penduduk (Schoorl, 1984:264). Menurut Wirth dalam (Schorl 1984:275) kehidupan dan kebudayaan urban ini akan membuat adanya segmentasi hubunganekonomi di kota memicu timbulnya sebuah kapitalisme. Kondisi kapitalisme di perkotaan membuat relasi sosial tidak terjadi antar personal, namun hubungan ini terjadi melalui perantara pasar dalam sebuah kegiatan konsumsi ( Rahmadian, 2012:31). Pada tulisan yang sama menurut Lasch :

"masyarakat kapitalis menempatkan mereka dalam posisi yang bertentangan satu sama lain di dalam lingkungan kompetitif tingkat tinggi dalam mencari pekerjaan dan keabsahan. Sementara itu pada saat yang bersamaan, orang dibebaskan dari ikatan-ikatan institusi (agama) dan kekeluargaan, yang pada akhirnya meninggalkan perasaan-perasaan kesepian serta terisolasi. Hal ini kemudian memunculkan implus-implus narsistik. Untuk melawan perasaan terisolasi itu, lanjut Lasch, kapitalisme menawarkan konsumsi sebagai penyembuh" ( Rahmadian, 2012:31).
\end{abstract}

Bila keadaan kota seperti apa yang digambarkan diatas, dan kehidupan masyarakat Indonesia kedepan mayoritas akan berada di kota tentu akan terjadi alienasi yang cukup besar dikalangan masyarakat. Perilaku individualis merupakan ciri utama sifat kehidupan kota, perilaku tersebut merupakan salah satu dampak permasalahan perkotaan, dengan demikian perilaku tersebut sangat sulit untuk dihilangkan (Sumardjito, 1999:135). Menurut Kuntowijoyo budaya massa adalah akibat dari masifikasi. Ini disebabkan karena dalam sektor budaya terjadi industrialisasi dan komersialisasi, sekalipun industrialisasi dan komersialisasi tidak selalu negatif bagi budaya. Bintarto dalam (Sumardjito, 1999:133) menerangkan, bahwa kesibukan setiap warga kota dalam tempo yang cukup tinggi dapat mengurangi perhatian terhadap sesamanya. Apabila hal ini berlebihan akan menimbulkan sifat acuh tak acuh atau kurang mempunyai toleransi sosial.

Alienasi sendiri menurut Marx dalam (Ritzer \& Goodman, 2013: 37-40) ada empat unsur yaitu teralienasi dari aktivitas produksi, teralienasi dari tujuantujuan produksi, teralienasi pada sesama pekerja dan teralienasi dari potensi kemanusiaan. Melihat hal tersebut dari konteks kehidupan pemuda kota menunjukan bahwa mereka telah teralienasi. Banyak pemuda bekerja bukan atas kesadaran ide-ide mereka namun digerakan oleh hal-hal yang dasarnya adalah uang, pasar, tren, dan sarana kapitalis lainnya. Pada akhirnya menghilangkan tujuan dari aktivitas mereka sendiri. Contoh terdekat adalah kehidupan mahasiswa di kampus. Mahasiswa kebanyakan belajar bukan lagi untuk pengembangan kualitas kapasitas diri, namun mereka kuliah semata-mata untuk mengejar ijazah sarjana saja. Fokus belajar kemudian semakin mengasingkan mereka dari kehidupan kampus, bahkan dengan teman-teman kuliah. Kemudian pada akhirnya yang semakin parah adalah mereka kehilangan esensi makna dari mahasiswa sendiri. Keadaan seperti ini dari sudut padang Fromm dapat 
dikatakan alienasi dimana seseorang mengalami dirinya sebagai sosok yang terasing. Orang tidak lagi melakukan sesuatu berdasarkan kehendaknya sendiri tetapi disetir oleh sesuatu di luar dirinya. (Nadhiroh, 2015:8)

Muncullah kebudayaan mainstream mahasiswa yang mengalienasikan mereka karena dampak kebudayan kapitalis kota. Ditengah kebudayaan utama tersebut masih terdapat beberapa komunitas-komunitas mahasiswa yang dianggap tidak wajar karena tidak melakukan aktivitas seperti mahasiswa pada umumnya. Semakin lama komunitas tersebut semakin berkembang dan bertentangan. Perkembangan ini kemudian dapat dilihat sebagai counter culture. Counter culture adalah budaya tandingan sebagai penolakan terhadap nilai-nilai masyarakat (Pickles, 200:6). Perlawanan pemuda pada dasarnya karena pemuda terbentuk dalam suatu artikulasi ganda yaitu dalam perlawanan dengan kebudayaan orang tua dan kebudayaan dominan. (Soleh, 2014:2). Salah satu komunitas yang tampak adalah organisasi pencinta alam yang sering disebut Mapala.

Ditengah pemuda lainnya yang lebih memilih menghabiskan waktu untuk kuliah atau mencari hiburan di mal, warung-warung kopi dan tempat semacamnya mereka justru lebih memilih untuk pergi ke alam terbuka yang jauh dari kata nyaman dan mapan. Tak heran kemudian ada beberapa orang yang mengidentikkan anak Mapala dengan orang-orang anti kemapanan atau mahasiswa paling lama. Kehidupan mereka yang terkesan semaunya sendiri menjadi pembeda yang jelas dari mahasiswa yang dianggap lurus-lurus saja. Jika demikian apakah kehidupan Mapala yang berbeda dari mahasiswa kebanyakan tersebut juga terhindar dari dampak budaya kota yang kapitalis? Tentu hal ini menjadi pertanyaan sendiri yang menarik untuk dibahas. Kemudian seberapa besar kontribusi Mapala berperan sebagai agen perubahan di tengah alienasi yang dianggap mengikis peran pemuda? Tentu hal tersebut perlu dan penting dijawab untuk bahan refleksi dan evaluasi pemuda saat ini.

Tulisan ilmiah mengenai pencinta alam dapat dilihat pada jurnal-jurnal seperti yang ditulis oleh Hendra Saputra, Silvia Kristanti T.F, dan Sukma Noor Akbar. Mereka melihat bagaimana peran pencinta alam terhadap perilaku anggota Mapala terhadap lingkungan. Tulisan tersebut menyebutkan bahwa pada organisasi Pencinta Alam Piranha terdapat peran kepemimpinan dalam membentuk prilaku posistif pro lingkungan (Saputra dkk, 2016). Tulisan tentang Pencinta Alam lebih banyak lagi dapat dibaca pada karya berupa skripsi. Konsep diri pada Mahasisiwa Pencinta Alam dibahas pada skripsi yang ditulis oleh Lasro Bonaventura Situmorang. Konsep diri yang digambarkan oleh Situmorang adalah hasil penelitian psikologi sosial. Pada tulisanya tersebut Situmorang menjelaskan bahwa anggota Mapala Sanata Dharma mempunyai konsep diri yang tinggi. Konsep diri yang tergambarkan baik positif seperti mahasiswa yang peduli lingkungan maupun negatif yakni mahasiswa yang kuliahnya lama (Situmorang, 2009).

Pada karya-karya tersebut menunjukan masih sangat minimnya pembahasan mengenai organisasi pencinta alam, khususnya dalam ranah sosial. Pembahasan bagaimana posisi dan peran pencinta alam kurang menggambarkan dinamika ataupun posisi mereka dalam ranah sosial yang lebih luas secara ilmiah. Jika kita melihat dari 
sejarah dan aktivitas yang dilakukan, kita tidak dapat menganggap remeh peran pencinta alam sebagai sebuah gerakan komunitas pemuda. Gambaran yang lebih kerap muncul, pencinta alam sebagai kelompok anak muda yang hanya suka naik gunung dan urakan. (Situmorang, 2009:26) Masyarakat umum terkadang tidak melihat kegiatan lain pencinta alam seperti kegiatan pelestarian alam, kampanye-kampanye hijau, kegiatan SAR atau kegiatan pemberdayaan di masyarakat. Di beberapa organisasi pencinta alam kampus bahkan mempunyai penekanan pada tri darma perguruan tinggi yang sangat jelas. Tentu dengan latar belakang seperti itu perlu kita melihat lebih seksama lagi.

Sedangkan tulisan ini adalah hasil dari penelitian singkat di lingkungan pencinta alam tingkat Universitas. Tulisan ini akan menunjukan bagaimana latar belakang, kehidupan sehari-hari yang menunjukan bentuk-bentuk perlawanan dari hegemoni budaya dominan dan peran pencinta alam pada masyarakat umum khusunya kampus. Penelitian yang dilakukan merupakan penelitian kualitatif yaitu menggunakan teknik wawancara mendalam, observasi partisipasi dan studi pustaka untuk mengumpulkan data. Informan yang dipilih adalah penggiat aktif pada sebuah mapala Universitas di Jogja yang memiliki latar belakang berbeda-beda. Penggiat ini ada yang sejak sekolah dulu sudah ikut dalam kegiatan pencinta alam dan yang baru saja ikut pada mapala tingkat Universitas. Data-data tentang sejarah dan hasil-hasil kegiatan dari organisasi pencinta alam dilengkapi dengan melakukan studi pustaka baik pada jurnal, buku, dan web yang berkaitan dengan organisasi pencinta alam.

\section{SEJARAH PENCINTA ALAM \\ MUNCULNYA}

Kelompok pencinta alam mulai bermunculan pada sekitar tahun 50an. Kata pencinta alam sendiri mulai muncul pada 18 oktober 1953. Nama pencinta alam pertama di usulkan oleh Awibowo pada tahun tersebut sekaligus dipakai menjadi nama perkumpulannya yakni Perkumpulan Pencinta Alam (PPA). Maksud dari berdirinya perkumpulan tersebut adalah untuk mewadahi hobi positif dan suci anak muda, dalam arti tidak maniak yang semata-mata melepaskan nafsu dalam hal negatif. Tujuan berdirinya kelompok ini adalah untuk memperluas dan meningkatkan kecintaan terhadap alam seisinya didalam kalangan anggotanya dan masyaraat umum (Duri, 2015:20). Perkumpulan ini beberapa tahun kemudian bubar karena kondisi politik yang tidak stabil. Kemunculannya kembali di tandai dengan adanya komunitas-komunitas pencinta alam di Jakarta dan Bandung. Setelah itu baru ada organisasi kepencintaalaman seperti MAPALA UI dan Wanadri. Kedua organisasi tersebut mulai muncul pada tahun 1960an. Mapala UI yang awalnya merupakan kumpulan mahasiswa sastra diantaranya terdapat tokoh seperti Soe Hok Gie.

Masih dalam perbincangan soal kesertaan tiga "anak luar" Mapala FS-UI, yaitu saya, Freddy dan Idhan, Maman menerangkan sikap Mapala FS-UI yang terkenal sebagai organisasi mahasiswa intern yang sangat ekslusif. Didirikan tahun 1964, kelompok inilah yang mencetuskan istilah pencinta alam untuk organisasi internal mahasiswa UI yang beraktifitas di bidang 
luar ruang (outdoor life) berupa perkemahan, perjalanan, dan pendakian gunung, termasuk kegiatan konservasi alam lestari. Organisasi kecil itu pun merupakan penampungan mahasiswa yang sudah jenuh, juga trauma, dengan prilaku organisasi kemahasiswaan yang bernaung di bawah parpol yang berkuasa di zaman orde lama.( Badil, 2009:3).

Pada awal mula perkembangan kegiatan kepencintaalaman masih berkisar tentang kegiatan-kegiatan konservasi dan penjelajahan hutan dan gunung. Kegiatan seperti susur goa, panjat tebing, dan arung jeram pada waktu itu masih jarang bahkan belum ada. Jika dibandingkan dengan kegiatan pencinta alam sekarang jauh lebih berkembang. Alasan utama belum berkembangnya kegiatan lainya yakni keterbatasan alat dan pengetahuan dari anggota pencinta alam dengan kegiatan lainnya tersebut. Kegiatan naik gunung yang mempunyai sejarah lebih panjang dari kegiatan yang lainnya ini membuat kesan bahwa pencinta alam adalah "anak gunung".

Dari kedua organisasi ini mulai bermunculan organisasi-organisasi kepencintaalaman baik dikalangan masyarakat umum maupun di lingkungan kampus-kampus. Seiring berjalannya waktu kemudian munculah sebuah kegiatan yang bernama Gladian yang dipelopori oleh Wanadri pada tanggal 25-29 Februari 1970. Gladian sendiri diambil dari kata "Gladi" dalam bahasa Jawa yang berarti berlatih. Dari kata tersebut kegiatan ini merupakan suatu wadah untuk berlatih bersama. Pada waktu itu perhimpunan yang diundang adalah perhimpunanperhimpunan pencinta alam di Jawa. Kemudian kegiatan ini berkembang tidak hanya menjadi wadah untuk latihan bersama namun juga mempertemukan organisasi-organisasi pencinta alam yang ada di Indonesia ${ }^{1}$. Seiring berjalannya waktu gladian ini berlangsung terus menerus hingga terakhir tahun 2009.

Dari sekian banyak gladian salah satu yang terpenting adalah gladian nasional ke IV di Ujung Pandang. Pada gladian Ke-IV ini disepakati sebuah kode etik. Kode etik ini kemudian disebut kode etik Pencinta alam. Kode Etik Pencinta Alam Indonesia dicetuskan pertama kali pada Januari tahun 1974. Kode Etik menjadi acuan dan pegangan teguh bagi para pencinta alam se-Indonesia dalam bersikap dan berperilaku dalam segala kegiatan di alam bebas. Gladian ini diselenggarakan oleh Badan Kerja Sama Club Antarmaja pencinta alam se-Ujung Pandang dan diikuti oleh 44 perhimpunan pencinta alam seIndonesia (Fitrianingsih, 2016:14). Kode etik tersebut hingga sekarang masih berlaku dan di gunakan oleh para penggiat Pencinta alam. Isi dari kode etik itu sendiri sebagai berikut :

\section{KODE ETIK PENCINTA ALAM INDONESIA}

PENCINTA ALAM INDONESIA SADAR BAHWA ALAM BESERTA ISINYA ADALAH CIPTAAN TUHAN YANG MAHA ESA.

${ }^{1}$ Lih tulisan secara lengkapa pada“Sejarah Gladian Nasional Pencinta Alam" majalah MAC: Adventure \& Culture Magazine edisi 3 


\begin{abstract}
PENCINTA ALAM INDONESIA SEBAGAI BAGIAN DARI MASYARAKAT INDONESIA SADAR AKAN TANGGUNG JAWAB KAMI KEPADA TUHAN, BANGSA DAN TANAH AIR.
\end{abstract}

\title{
PENCINTA ALAM INDONESIA SADAR BAHWA PENCINTA ALAM ADALAH SEBAGAI MAKHLUK YANG MENCINTAI ALAM SEBAGAI ANUGERAH TUHAN YANG MAHA ESA.
}

Sesuai dengan hakikat diatas kami dengan kesadaran menyatakan :

1. Mengabdi kepada Tuhan yang Maha Esa.

2. Memelihara alam beserta isinya serta menggunakan sumber alam sesuai dengan kebutuhanya.

3. Mengabdi kepada bangsa dan tanah air.

4. Menghormati tata kehidupan yang berlaku pada masyarakat sekitar serta menghargai manusia dan martabatnya.

5. Berusaha mempererat tali persaudaraan antara sesama pencinta alam sesuai dengan azaz pencinta alam.

6. Berusaha saling membantu dalam pelaksanaan pengabdian terhadap tuhan,bangsa dan tanah air.

7. Selesai.

(Disahkan pada Gladian IV Ujung Pandang)

Bermula dari kesamaan kesenangan dan hobi ditambah dengan tidak nyamannya orang-orang pada keadaan lingkungan mereka baik di kampus maupun di kota akhirnya terbentuklah kelompok-kelompok seperti yang diterangkan diatas. Kelompok ini semakin mapan dengan tujuan dan aturan yang mereka buat. Aturan dan tujuan sendiri secara jelas dapat dirujuk dari kode etik pencinta alam tersebut. Kode etik ini kemudian menjadi kunci bagi kehidupan pencinta alam, sehingga kode etik yang dibuat pada tahun 1974 begitu penting dalam sejarah pencinta alam Indonesia.

Ikatan pertemanan ini dilandasi selain dari nilai turun-temurun yang selalu diwarisi dari kakak angkatan kepada juniornya, dan sistem informal seperti norma yang sudah tercipta di lingkungan pencinta alam. Secara formal hal ini juga dipengaruhi dari kode etik pencinta alam sendiri seperti yang tertulis pada butir ke lima yakni "Berusaha mempererat tali persaudaraan antara sesama pencinta alam sesuai dengan asas pencinta alam." Sehingga sangat wajar dan normal ketika seorang pencinta alam saling berhubungan hangat meski sebelumnya belum pernah kenal atau bertemu. Keadaan seperti ini membuat saling terikatnya ikatan pencinta alam. Ikatan ini kemudian dapat dilihat pada wujud-wujud seperti forum yang terbentuk antara kelompok pencinta alam baik secara regional maupun segmentasi lain seperti Temu Wicara dan Kenal Medan (TWKM). TWKM ini sebuah forum untuk pencinta alam tingkat universitas se-Indonesia.

Forum ini mengagendakan pembahasan isu-isu lingkungan terkini dan latihan teknik-teknik petualangan yang langsung dipraktekan di lapangan. Kondisi-kondisi solidaritas yang terjadi di gunung atau kegiatan-kegiatan lapangan lain terbawa hingga dalam kehidupan keseharian pencinta alam. Ikatan ini biasanya timbul karena ada suatu kegiatan yang diadakan bersama sehingga saling kenal, atau karena ketidaksengajaan kenal di lapangan 
saat naik gunung bersama, menyusuri goa, atau manjat, rafting dan lain sebagainya, atau memang pertemanan itu timbul dari perjumpaan di sekre (tempat berkumpul) ketika ada yang bertamu.

Sejarah terbentuknya pencinta alam sendiri selain berdampak pada tumbuhnya budaya solidaritas yang kuat, juga memberikan corak yang cukup kuat pada kegiatan-kegiatan yang dilakukannya hingga saat ini. Pencinta alam yang tumbuh diakhir orde lama dimana suasana politk begitu kuat dan kemiskinan sangat tinggi, membuat orang-orang sangat jenuh dengan politik dan kegiatan ini menjadi salah satu pilihan untuk mengimbangi keadaan yang penuh politik tersebut, dalam kata lainnya sebagai katarsis. Mereka juga menjadi sangat interes pada kehidupan masyarakat kecil terutama orang-orang disekitar gunung. Kemiskinan yang sangat tinggi membuat mereka tergerak untuk menjalin sebuah hubungan dengan masyarakat sehingga kegiatan mereka tidak hanya soal petualangan. Dari situlah muncul berbagai bentuk kegiatan pengabdian pada ekspedisiekspedisi yang dilakukan pencinta alam hingga sekarang. (Badil, 2005:136)

\section{KESEHARIAN PENCINTA ALAM}

Kehidupan anggota pencinta alam sering digambarkan dengan kehidupan yang bebas, penuh petualangan, dan sibuk dengan kegiatan luar ruang. Masyarakat pada umumnya melihat pencinta alam hanya sebatas dari sisi kegiatan di alam saja. Mereka jarang melihat kehidupan keseharian anak pencinta alam. Dinamika anggota pencinta alam tidak jauh berbeda degan interaksi kehidupan sehari-hari pada umumnya. Di dalamnya terdapat interaksi-interaksi berupa keakraban, solidaritas, pemenuhan kebutuhan, perbedaan pendapat, perselisihan, problem solving yang dilakukan di lapangan, juga di sekretariat mereka. Interaksi tersebut mulai dari yang formal seperti rapat anggota, perencanaan, pelaksanaan kegiatan, evaluasi setelah kegiatan, pendaftaraan dan penerimaan anggota baru. Secara tidak formal sekretariat juga tempat berkumpulnya anggota pencinta alam sendiri melakukan berbagai aktivitas (Situmorang, 2009:27). Kehidupan anggota pencinta alam khususnya MAPALA banyak menghabiskan waktu mereka di sekretariat. Banyak dari mereka yang memiliki rumah atau kos-kosan sendiri lebih memilih menginap dan bermalam di sekretariat.

Sekretariat akhirnya menjadi rumah kedua bagi para anggota pencinta alam. Berbagai alasan muncul kenapa mereka banyak menghabiskan waktu di sekretariat. Jawaban setiap personal anggota pencinta alam bisa berbeda dan subjektif, namun secara garis besar terdapat beberapa alasan yang latar belakang mereka banyak menghabiskan hidup di sekretariat. Pertama kegiatan Mapala yang berlangsung hingga larut malam. Kegiatan-kegiatan ini seperti latihan, rapat, persiapan sebuah pengembaraan dan masih banyak lainnya sehingga mereka malas untuk pulang ke kosan atau rumah. Kedua adalah alasan kenyamanan, alasan ini timbul karena rasa solidaritas yang tinggi dari para anggota yang mendorong adanya rasa nyaman tersebut, sebab di sekretariat mereka akan banyak menjumpai teman untuk mengobrol, nongkrong bareng dan kegiatan sejenisnya. Ditambah dengan kehidupan bebas yang 
terkadang terlihat seperti maunya sendiri.

Gambaran kehidupan keseharian pencinta alam dapat sangat mudah ditemui pada organisasi-organisasi pencinta alam di kampus. Di tengah kehidupan kampus akan terlihat kontras antara para mahasiswa pencinta alam ini. Di sekretariat Mapala terlihat mereka sering nongkrong hingga larut malam, kemudian mereka tidur di sekre setelah larut malam. Akhirnya siang hari baru bangun, sedangkan mahasiswa lain kebanyakan sudah masuk ke ruang kuliah atau melakukan aktivitas lainnya. Tak heran bila banyak orang yang mengecap Mapala adalah kepanjangan dari mahasiswa paling lama. Anggota Mapala dicap jarang masuk kuliah kemudian nilai mereka jelek dan banyak mengulang mata kuliah. Di lingkungan Mapala sendiri terkadang tabu membicarakan masalah perkuliahan, apalagi sampai menanyakan angkatan kuliah, kapan lulus dan pertanyaan semacamnya seputar akademis. Seorang Mapala yang memasuki semester akhir ketika mereka ditanyai masalah seputar akademis biasanya dia akan menjawab berbohong atau mengalihkan topik dengan candaan-candaan. Fenomena ini menunjukan sisi counter coulter mereka. Aktivitas di sekretariat merupakan bentuk kebosanan mereka akan aktivitas pada umumnya. Mereka merasa tidak puas hanya mencari ilmu di bangku kelas, mereka juga ingin mencari pengalaman lainnya. Mereka sadar jika kegiatan Mapala ini akan banyak berbenturan dengan perkuliahan, namun bagi mereka kuliah bukan hanya soal rajin masuk kelas dan mendapat IPK tinggi. Bagi mereka ada ilmu-ilmu yang juga harus dicari di luar bangku kuliah sebagai pengembangan diri mahasiswa. Adanya stereotip Mapala adalah mahasiswa paling lama menunjukan jika masyarakat melihat Mapala sebagai organisasi yang tidak sewajarnya mahasiswa.

Kehidupan keseharian di Mapala membuat timbulnya sikap komunal pada anggotanya, mereka tak jarang saling mengandalkan untuk berbagai hal aktivitas. Sering antar anggota meminta dijemput disuatu tempat dengan cuma-cuma, atau minta "direscue" bahasa mereka untuk meminta pertolongan baik yang remeh temeh seperti kehabisan bensin dijalan, ban bocor, tidak membawa uang, sampai sakit atau benar-benar pada kondisi yang genting. Berbagi rasa lapar sudah menjadi hal yang sangat wajar apalagi ketika tanggal tua mereka tak jarang untuk makan bersama.Cara mereka makan bersama ini dengan menggelar kertas minyak kemudian nasi dituang merata begitu pula dengan sayur dan lauknya, setelah itu mereka mengkrubuti makanan itu secara bersama. Barang-barang milik pribadi menjadi seperti barang bersama karena pinjam-meminjam sangat wajar. Ditambah keterbatasan ekonomi maupun hal-hal lain pada anggota menambah rasa komunal tersebut. Kehidupan yang dijalankan oleh para anggota Mapala di atas menunjukan rasa kekeluargaan yang intim sehingga membongkar sekat-sekat batasan pribadi. Sudah tidak ada gengsi lagi antar anggota atas keadaan diri mereka masing-masing, justru keadaan yang kurang dari individu terkadang jika dapat dibantu ditutup oleh individu yang mampu membantunya. Sikap individualis dalam iklim lingkungan yang seperti ini akan sulit untuk muncul. 
Solidaritas yang digambarkan itu tidak sebatas hanya pada anggota intern pada suatu kelompok pencinta alam, namun juga antar kelompok pencinta alam lainnya di Indonesia. Ada sebuah cerita menurut informan, seorang penggiat pencinta alam dari Bandung melakukan sebuah perjalanan ke Maluku. Setelah dari Maluku ia pergi ke Nusa Tenggara Barat untuk mendaki gunung Rinjani, pada saat perjalanan uang dia habis dan hanya bisa untuk beli tiket pulang sampai Jogja saja. akhirnya orang ini memutuskan untuk pulang sampai di Jogja. Sesampainya di Jogja ia menyambangi salah satu organisasi pencinta alam disana. "ya kan saya bingung udah gak punya uang nih yaudah cuma kepikiran ke Jogja aja nanti numpang makan di sana, pulang nya nanti gak tau"2 ungkap orang tersebut. Ketika di Jogja oleh tuan rumah yaitu anggota Mapala setempat ia diberikan makan juga dijamu beberapa hari sampai akhirnya mendapat kiriman uang untuk beli tiket pulang ke Bandung. Masalah jamumenjamu pada kehidupan pencinta alam memang tidak asing dan sangat wajar. Sudah menjadi sebuah etika ketika kita kedatangan seorang tamu untuk menjamunya dan menolong mereka dengan baik dan layak. Hubungan ini sangat erat diseluruh Indonesia, bahkan ketika ada organisasi yang kurang baik memperlakukan tamu dapat menjadi bahan gunjingan, bahkan sampai terbuka menjadi omongan umum. Kebiasaan ini menumbuhkan keterbukaan dan rasa sosial anggota Mapala. Organisasi Mapala menjadi sangat sering menerima tamu dari Mapala di seluruh Indonesia dari Mapala yang memang sudah ia kenal hingga yang belum pernah ia dengar nama Mapalanya bahkan kampusnya. Mereka pada akhirnya terbiasa ringan tangan untuk menolong orang asing yang membutuhkan meskipun sebelumnya belum ia kenal sama sekali. Tentu hal ini membantu para anggota untuk tetap mempertahankan eksistensi mereka sebagai mahluk sosial sesuai kodrat manusia.

Anggota-anggota baru pada organisasi ini tak luput dari doktrin kehidupan komunal. Mereka didoktrin secara tidak langsung dengan cara menuntut anggota baru untuk menjadi pesuruh menjamu tamu. Sebagai junior mereka sering disuruh untuk membuatkan minuman seperti teh atau kopi untuk para tamunya. Anggotaanggota baru ini juga kerap disuruh untuk pergi beli makanan yang kemudian dimakan bersama-sama dengan tamu atau menjadi guide di kota tersebut. Hal ini menjadi salah satu tugas pokok para anggota baru dengan dalih agar belajar bagaimana memperlakukan tamu dengan benar. Bagi para anggota baru mereka baru masuk pada tahapan internalisasi nilai pencinta alam. Disini menunjukan bahwa Mapala mempunyai nilai dan sistem pengkontrolan nilai, sehingga Mapala sebagai organisasi tidak hanya diatur oleh individu-individu yang ada didalamnya namun juga dapat mengatur atau membudayakan individu yang ada didalamnya sehingga memiliki nilai yang menjadi tujuan pencinta alam. Disisi lain terdapat kehidupan bebas anggota Mapala. Kehidupan yang bebas ini jika diamati hampir sama dengan kehidupan bebas para seniman-seniman. Hal ini terjadi karena banyak anak-anak pencinta alam yang "nyeni", baik suka musik, berpuisi, atau melukis. Di sekretariat pencinta alam hampir selalu dapat ditemui sebuah gitar. Alat ini menjadi salah satu pengisi aktivitas di tempat

2 Keterangan adalah hasil wawancara dengan informan anggota salah satu Mapala di Jogja. 
itu. Di sekretariat ketika obrolan sudah membosankan maka biasanya mereka akan beralih dengan gitaran dan bernyanyi bersama. Bermain gitar dan bernyanyi hingga larut bukan saja menjadi aktivitas rutin di sekretariat namun juga saat camping. Ditemani dengan api unggun sambil melakukan bakar-bakaran atau hanya sekedar melingkar mengelilingi api unggun mereka bernyanyi bersama. Adanya perkembangan teknologi juga membuat suatu perubahan di kalangan pencinta alam. Jika dulu ingin mendengarkan musik diatas gunung mereka harus membawa gitar, sekarang mereka lebih sering menggunakan HP dengan dilengkapi sound sistem kecil portable.

Penampilan seorang pencinta alam juga dapat menggambarkan kehiduapn mereka yang bebas. Rambut gondrong, dekil, anti kemapanan, berpakaian lusuh kumal memakai gelang tali perusik, banyak ditangan dan kalung menjadi salah satu gambaran umum yang banyak digambarkan masyarakat. Penampilan ini terkesan semakin santai ditambah gaya anak-anak pencinta alam yang santai, hangat dan terlihat "selo". Namun ada juga yang memandang anak-anak pencinta alam itu menakutkan dan liar. Memang sudah menjadi setengah candaan dan kenyataan bagi mereka saling mengolok "mandi dulu sana", "ih gembel banget lu", " heh buluk" dan candaan semacamnya. Kebiasaan saat di gunung tidak mandi memang sering terbawa pada keseharian anak-anak pencinta alam. Berhubungan dengan

"Konsep diri adalah gambaran atau pandangan secara menyeluruh mengenai diri oleh individu yang bersangkutan, dari konsep diri ini akan menentukan bagaimana individu tersebut berperilaku, merasakan dan merespon lingkungannya. Individu yang memilki konsep diri yang positif menghasilkan bentuk prilaku yang mandiri, menghargai diri sendiri dan orang lain serta percaya diri yang tinggi, dalam artian konsep diri yang positif mempengaruhi perilaku yang konstruktif. (Situmorang, 2009:50)"

Kebiasan-kebiasan ini justru membuat yang normal pada masyarakat umum menjadi tidak normal bagi kelompok kegiatan-kegiatan yang dilakukan di alam bebas seperti pendakian gunung, menghabiskan waktu cukup lama di gunung, bisa berkisar tiga hari sampai satu minggu maka diri fisik pun akan terkena imbas dengan kegiatan tersebut (Situmorang, 2009:26).

Selain itu dengan siklus hidup mereka yang kebanyakan beraktivitas di malam hari dan baru bangun di siang hari membuat mereka hanya mandi sekali dalam sehari. Mandi saat siang atau menjelang sore telah mewakili mandi pada pagi hari sekaligus sore hari. Penampilan dan perilaku Mapala tersebut menunjukan sebuah citra atau bisa disebut konsep diri. Konsep diri mengorganisasikan persepsi di dalam suatu sistem kerja otak kemudian diaplikasikan dalam bentuk prilaku, artinya pelaku individu dipengaruhi oleh persepsi dari konsep diri yang dimiliki menurut Choney konsep diri memiliki peran pada pembentukan perilaku. Dengan teori looking glass self menyatakan konsep diri mempengaruhi perilaku yang merupakan hasil dari penilaian atau evaluasi terhadap diri sendiri dan pendapat orang lain. (Situmorang, 2009:30). Peran konsep diri dengan demikian penting untuk Mapala, terutama dalam mengkonstruksi tindakan mereka seperti yang disebutkan :

mereka. Ketika ada salah satu anggota yang menggunakan baju secara rapi justru menjadi pertanyaan bagi mereka dan 
kadang juga berujung cemoohan dan candaan. Kondisi ini tidak hanya berlaku bagi anak laki-laki saja namun termasuk juga pada perempuan. Bagi perempuan terkadang justru candaan untuk mereka lebih parah dari pada kepada anak lakilaki. Ketika anak perempuan memakai rok, make up atau bahkan gincu saja permasalahan bisa lebih panjang dan bullyan akan lebih parah. Budaya seperti yang digambarkan diataslah yang sering dianggap bebas oleh masyarakat umum, dan bagi anggota sendiri justru menjadi sekat pembatas.

\section{KEGIATAN LAPANGAN SEORANG PENCINTA ALAM}

Kegiatan outdoor menjadi motor utama dari organisasi ini. Kegiatan outdoor merupakan sarana menjalankan organisasi pencinta alam, baik untuk menjaring minat anggota baru maupun sebagai alat transfer nilai-nilai kepencintaalaman (Situmorang, 2009:27). Pencinta alam bahkan bisa dikatakan bukan pencinta alam jika tidak terdapat kegiatan outdoor didalamnya. Hal tersebut karena sejarah panjang pencinta alam yang kemudian telah membuat citra yang begitu melekat pada masyarakat bahwa pencinta alam adalah organisasi berbasis petualangan. Dibalik kegiatan outdoor terselip nilainilai yang ditanamkan seperti lebih peduli dengan alam dan sekitarnya, lebih menghayati dan lain sebagainya.

Pada kegiatan alam ini pencinta alam sangat menekankan pada pengetahuan mereka dalam berkegiatan di alam terutama bagaimana melihat resiko dari aktivitas mereka. Para anggota pencinta alam pada akhirnya akan dituntun mempunyai persiapan yang matang ketika hendak mengadakan kegiatan di alam. Hal ini sangat utama dan penting bagi mereka. Mereka sering menyebut ini dengan manajemen kegiatan. Manajemen kegiatan disusun hingga sangat detail, bahkan untuk kegiatan-kegiatan tertentu yang sifatnya pendidikan mereka diwajibkan untuk mempresentasikan kesiapan mereka. Presentasi inilah kemudian menjadi forum untuk anggota yang akan berangkat dan yang tidak berangkat baik dari anggota aktif hingga senior memberikan masukan. Forum tersebut menjadi ajang cek and control bagi organisasi. Bagi anggota yang akan berangkat hal ini bukan sekedar presentasi biasa karena mereka harus juga siap untuk berargumen kenapa mereka memilih kegiatan, tempat dan hasil kegiatan tersebut. Mereka harus dapat mepresentasikan tujuan kegiatan mereka.

Saat aktivitas di lapangan anggota dilatih untuk siap menghadapi segala kondisi. Tidak ada perbedaan gender ketika dilapangan baik perempuan maupun laki-laki mereka memiliki tanggung jawab yang sama. Anggapan bahwa alam tidak akan memperlakukan berbeda pada perempuan maupun laki-laki menjadi dasarnya. Ketika naik gunung perempuan sama-sama harus membawa carier dengan ketentuan-ketentuan Standar Operasional Prosedur (SOP) yang telah disyaratkan, mempersiapkan fisik sesuai standar-standar minimum, tidur sama-sama di tenda yang sama. Sebegitu berbedanya kondisi antara kehidupan sehari-hari dengan di lapangan hingga anggota mempunyai suatu anggapan bahwa kamu akan tahu sifat asli temanmu saat di gunung. Mereka berpendapat pada kondisi yang minim itu lah kemudian orang-orang tidak lagi bisa berpura-pura untuk menghadapi keadaan. Jika ada orang yang egois, manja tidak mau repot, tidak disiplin dan lain sebaginya akan terlihat begitupun sifat-sifat sebaliknya.

Sifat-sifat asli ini kemudian perlahan dirubah dengan nilai-nilai yang ada di organisasi terutama yang dianggap 
penting seperti egosi, disiplin, dan tidak mau repot. Penggeseran nilai ini melalui kegiatan-kegiatan persiapan, kegiatan di lapangan ataupun saat proses pendidikan. Bentuk dari penanaman ini bisa berupa dari SOP kegiatan maupun aturan organisasi yang ditetapkan atau atauran yang tidak tertulis langsung dan disampaikan dengan lisan.

Pada praktiknya kemudian seperti kegiatan pendakian gunung anggota Mapala akan membagi tugas pada setiap anggota yang mengikuti pendakian. Tugas itu menjadi tanggung jawab orang yang telah ditetapkan, sehingga tim tidak akan berjalan jika ada salah satu bagian tidak berjalan. Secara tidak langsung orang tersebut diajak untuk berpikir bahwa keberlangsungan tim tidak bisa dibebankan pada satu orang tapi bertumpu pada ke semua orang dengan tanggung jawab pada bagian yang ia pegang. Berangkat bersama pulang juga bersama menjadi prinsip dari mereka.Tidak dibenarkan jika saat naik gunung, mereka jalan masing-masing mementingkan kepentingannya tidak memperhatikan teman rombongannya. Dari itu kemudian muncul istilah saling backup, dalam artian bahwa setiap anggota kelompok harus memperhatikan dan menjamin keadaan temannya. Sangat pantang bagi anggota pencinta alam pulang duluan tanpa tahu keadaan anggota lainnya, tanpa kesepakatan sebelumnya.

\section{PENCINTA ALAM KELESTARIAN ALAM}

Kegiatan Mapala selain naik gunung atau susur goa, panjat tebing, arung jeram, dan kegiatan petualangan lainya ternyata ada kegiatan yang bisa di kategorikan non petualangan. Pencinta alam juga sering melakukan kegiatan seperti penelitian, atau pengabdian masyarakat dan konservasi. Beberapa organisasi pencinta alam benar-benar menekankan pentingnya kegiatan di luar petualangan tersebut, terutama kegiatan konservasi. Kegiatan konservasi menjadi bentuk aktualisasi dari kecintaan dan kepedulian pencinta alam terhadap lingkungan. Bentuk dari kegiatan ini sangat bermacam-macam mulai dari kegiatan menanam pohon bersama, kegiatan bersih sungai, bersih sampah di lingkungan tertentu. Beberapa organisasi pencinta alam kegiatan konservasi dalam struktur kelembagaan menjadi suatu divisi tersendiri sama halnya dengan naik gunung, susur goa, panjat tebing, arung jeram, dan lainnya. Tentu ini menegaskan bahwa pencinta alam bukan hanya seorang penikmat alam, namun benarbenar mencintai alam dan isinya.

Adapun kondisi alamiah yang kemudian 'menggembleng' secara natural anggota. Seperti keterbatasan fasilitas di gunung, gua, ataupun sungai. Mereka tidak dapat membawa baju banyakbanyak dan ganti setiap saat, tidak dapat tidur nyaman di kasur empuk, penerangan tidak ada setiap saat. Kenyamanan yang bisa dibilang jauh dari kehidupan seharihari membuat mereka mudah beradaptasi dengan berbagai keadaan lingkungannya maupun pribadi dalam tim. Penanaman rasa kesadaran untuk tidak merusak alam diterapkan pada setiap kegiatan seperti tidak meninggalkan jejak sampah di alam. Misalnya di gunung tidak membuang sampah sembarang, menyimpan puntung rokok hingga benar-benar memastikan meninggalkan bekas perapian padam sempurna. Para aktivis penelusur gua juga mempunyai semboyan yang cukup terkenal "take nothing but picture, leave nothing but footprint, kill nothing but time". Beberapa contoh dari aspek tingkah laku lainnya sebagai seorang anggota pencinta alam yang memiliki kepedulian terhadap lingkungan hidup, dalam aplikasinya mereka adalah orang-orang 
yang tidak membuang sampah maupun puntung rokok sembarangan, namun mengantonginya terlebih dahulu sebelum menemukan tempat sampah lalu dibuang (Situmorang, 2009:51-52). Pada intinya kegiatan ini memberikan beberapa garis besar yaitu penggemblengan mental pribadi, kepedulian kelestarian dan kepedulian sekitar.

Dari sekian banyak bentuk kegiatan konservasi tersebut dapat digolongkan menjadi kegiatan yang bentuknya wacana, aksi nyata yang terbatas pada intern kelompok dan aksi nyata melibatkan pihak luar. Bentuk dari kegiatan yang bersifat wacana ini seperti diskusi, membuat tulisan atau membuat sebuah kampanye. Harapan dari kegiatan tersebut adalah timbul penyadaran akan pentingnya kepedulian orang terhadap lingkungan. Ide yang dibawa biasanya bisa dari hal yang kecil-kecil hingga sebuah ide terhadap isu besar. Bentuk lainnya yakni aksi nyata namun terbatas hanya pada intern kelompok, maksudnya adalah bahwa kegiatan semacam ini biasanya dilakukan bukan lagi hanya pada tataran ide seharusnya bagaimana tapi sudah pada tahapan tindakan. Tindakan yang mereka lakukan namun belum melibatkan pihak di luar kelompok, sehingga kegiatan yang dilakukan masih sebatas pengimplementasian ide pada kelompok tersebut. Bentuk yang terakhir adalah aksi nyata yang sudah melibatkan pihak di luar kelompok ini. Ide atau gagasan yang dikembangkan pada bentuk ini ditransfer pihak pencinta alam pada orang-orang di luar kelompoknya, tentu pada tahapan ini ada tindakan dan interaksi nyata oleh pihak luar.

Setiap tahunnya mahasiswa pencinta alam pada tingkat perguruan tinggi selalu melakukan pertemuan ditingkat nasional. Pada rangkaian ini dibagi menjadi dua kegiatan utama yakni diskusi prihal masalah lingkungan dan yang satunya lagi adalah kegiatan lapangan bersama. Acara ini disebut dengan TWKM yakni kepanjangan dari temu wicara dan kenal medan. Pada acara inilah kita dapat melihat secara langsung bagaimana kelompok pencinta alam membuat kegiatan dalam mengembangkan wacana peduli terhadap lingkungannya terutama pada bagian diskusinya atau disebut temu wicara. Pada temu wicara ini setiap delegasi akan membawa isu atau masalah lingkungan yang ada di wilayahnya. Kemudian pada forum itu akan dipilih beberapa isu yang dapat diangkat sebagai isu nasioanal, atau dipilih sebagai isu yang krusial untuk didiskusikan. Hasil dari temu wicara dari tahun ketahun berbeda-beda bisa hanya sebuah petisi atau kampanye nyata, tergantung forum pada saat diskusi. Kegiatan lainnya adalah pembuatan tulisan yang di publikasikan dimasingmasing media organisasi yang tentunya memuat berbagai isu lingkungan. Konten dari tulisan sangat bermacam baik dari isunya maupun pendekatan yang digunakan, hal itu sangat dipengaruhi latar organisasi dan individu yang menulis. Contoh lain adalah mengadakan workshop tentang pengelolaan sampah bersama dinas terkait, pemutaran film-film yang bertemakan pemanasan global (Situmorang, 2009:51-52).

Akhir-akhir ini isu yang dikembangkan oleh pencinta alam ternyata tidak hanya sebatas isu lingkungan saja, namun juga berkembang pada isu-isu standar keamanan berkegiatan di alam. Isu ini muncul karena pesatnya wisata alam seperti pendakian gunung. Mereka melihat banyak pendakipendaki yang melakukan aktifitas ini tanpa pengetahuan akan resiko pendakian gunung dan persiapan-persiapan yang minim. Efek dari tren mendaki ini 
berakibat pada banyaknya kasus di gunung. Akhirnya mereka tergerak untuk berbagi pengetahuan berkegiatan di alam bebas agar tidak berujung pada keadaan yang tidak diinginkan. Bagi Mapala hal itu merupakan tanggung jawab mereka untuk mengedukasi masyarakat luas sebagai pihak yang sering melakukan kegiatan alam bebas.

Penanaman pohon, bersih sungai adalah kegiatan nyata yang sering dilakukan oleh pencinta alam sebagai bentuk dari kegiatan konservasi. Kegiatan semacan ini dilakukan pada tingkatan intern organisasi saja. Kegiatan ini dilakukan untuk menunjukan kontribusi nyata organisasi pencinta alam terhadap lingkungan. Pada kegiatan ini ada sebuah penanaman nilai pada anggotanya untuk peduli dengan lingkunganngya. Seiring berkembangnya waktu isu tentang lingkungan berkembang. Kelompok pencinta alam tidak hanya dituntut untuk melihat hutan atau sungai yang jauh dari kehidupan keseharian. Mereka juga mulai diajak untuk melihat lingkungan sekitarnya yang paling dekat. Contoh nyatanya adalah ketika para anggota berkegiatan di alam bebas seperti pendidikan gunung dan penelusuran gua, sampah-sampah seperti sampah plastik, puntung rokok, kaleng bekas, botol, batu baterai, dan sampah-sampah tidak bisa diuraikan oleh alam tidak ditinggal begitu saja atau dibuang sembarangan melainkan dibawa kembali pulang dan dibuang ditempat sampah Tingkah laku seperti ini menjadi kebiasaan bagi sebagian anggota dan diterapkan dalam kehidupan di kota (Situmorang, 2009: 30). Contoh lain adalah dengan mengadakan workshop tentang pengelolaan sampah bersama dinas terkait, pemutaran film-film yang bertemakan pemanasan global dan pengadaan penanaman bibit pohon di daerah-daerah yang mengalami krisis dan tandus dengan tujuan dari kegiatan ini adalah untuk menjaga kelestarian lingkungan hidup. (Situmorang, 2009:5152)

Pada akhirnya yang lebih riil mereka melakukan kegiatan yang dapat membantu kelestarian lingkungan sekitar meski dengan kegiatan kecil seperti membuat kebun di sekretariat mereka, membuat ecobrick dari sampah di sekre (panggilan untuk ruang sekretariat). Di belakang kantor sekretariat mapala mitapasa terdapat beberapa bibit pohon yang sekarang sulit dijumpai karena kelangkaanya, hasil penyelamatan anggota. Yang nantinya akan ditanam di beberapa titik sekitar kampus, untuk mengupayakan kampus tetap hijau (Fitrianingsih, 2016: 58). Pada intinya peningkatan kesadaran lingkungan dikembangkan tidak hanya secara monoton dan klasik dengan parameter lebatnya hutan dan bersihnya sungai yang ada jauh di lingkungan keseharian. Di daerah perkotaan pun ada masalah dan tanggung jawab yang harus mereka selesaikan mulai dari hal terkecil. Seperti pada kasus diskusi pembuatan wacana isu permasalahan dampak kegiatan wisata alam bebas juga muncul dan ramai dibicarakan.

Beberapa kelompok juga membuat edukasi berkegiatan yang ramah lingkungan secara nyata. Seperti yang dilakukan oleh PALAWA UNPAD mereka tahun lalu melakukan ekspedisi ke puncak Cartenz. Selain melakukan pendakian mereka membawa misi mengkampanyekan Zero Waste Mountaineering dan melakukan pendataan faktor penghambat upaya literasi di desa yang letaknya tak jauh dari puncak yakni di Desa Ugimba. "Ekspedisi Padjadjaran Nemangkawi 2016" diharapkan mampu mengulas banyak tentang Fenomena Petualangan dan 
Pendidikan di Tanah Papua. Wujud nyata yang diharapkan adalah dihasilkannya buku dan film tentang Zero Waste Mountaineering serta fenomena pendidikan di Desa Ugimba. ${ }^{3}$ Dari kegiatan ini seperti membangun perpustakaan, mengajar di sekolahsekolah terpencil selama ekspedisi. Dengan kampanye seperti diatas dapat diharapkan para wisatawan sadar akan dampak keberadaan mereka di alam bebas.

\section{SAMBUNG RASA LEWAT KEGIATAN PENCINTA ALAM}

Search and Rescue kemudian lebih popular dengan SAR menjadi bukti bentuk kepedulian Pencinta alam terhadap rasa kemanusiaan. Pada pendidikan dasar materi SAR menjadi materi utama. Hal ini menunjukan bagaimana nilai-nilai kemanusian SAR ditanamkan oleh organisasi pencinta alam. Nilai-nilai SAR ini tidak secara eksplisit dikatakan seperti penanaman nilai-nilai kemanusian, mereka lebih membahasakan dengan tanggung jawab kita terhadap lingkungan kita, dan merupakan peran mereka sebagai organisasi Pencinta alam. Muatan SAR ini juga menjadikan tolak ukur mereka untuk membedakan antara komunitas atau orang-orang yang hanya naik gunung sebagai hobi atau hiburan. Pemupukan kepedulian ini pada akhirnya sering dipraktekan secara kecil-kecilan saat naik gunung, semisal menolong orang yang kakinya terkilir, berbagi bekal, memberikan informasi ketika kondisi medan atau cuaca buruk. Tindakan kecil itu merupakan turunan dari rasa

${ }^{3}$ Lih uraian berita secara lengkap padaTika Amanda "Ekspedisi Padjadjaran Nemangkawi 2016 pada" http://palawa.unpad.ac.id/2016/07/21/ekspedisipadjadjaran-nemangkawi-2016/

${ }^{4}$ Lih uraian berita secara lengkap pada ISVK, M-920-

UI “Operasi SAR Waraga Depok di Sungai Ciliwung"http://mapala.ui.ac.id/2017/03/operasi-sarwarga-depok-di-sungai-ciliwung kepedulian mereka terhadap orang lain ketika berkegiatan.

Pencarian warga yang hanyut di Sungai Ciliwung Depok menjadi salah satu bagaimana peran Pencinta Alam dan berbagai lembaga terkait melakukan operasi SAR. Tim SAR merupakan gabungan dari Mapala UI, Basarnas, Komunitas Ciliwung Depok, Mapa Gunadarma, Tagana, Sekber Sahabat Ciliwung, Tagana, PMI Depok, I-Deru, dan PGI Jabodetabek. Tim gabungan tersebut menunjukan bagaimana peran pencinta alam dalam kegiatan kemanusiaan ${ }^{4}$. Adapun Regu khusus penyelamat Korpala Unhas melakukan evakuasi korban yang terjatuh di Gua Dinosaurus Kabupaten Maros Sulawesi Selatan pada hari minggu 15 Mei 2016 pukul 10.15 WITA $^{5}$. Kedua kegiatan tersebut menunjukan bahwa kemampuan mereka dalam hal berpetualang dapat juga digunakan untuk membantu proses-proses SAR, dan tentu yang paling penting juga kemauan mereka untuk memanfaatkan kemampuan mereka dalam SAR. Adapun bentuk kegiatan kemanusiaan lainnya dapat berbentuk seperti tanggap bencana. Tanggap bencana ini bisa seperti penggalangan bantuan seperti saat ini yang dilakukan untuk para pengungsi Gunung Agung di Bali. ${ }^{6}$

Pernah suatu ketika mahasiswa dari perguruan tinggi di Jogja mendaki Gunung Sindoro. Pendaki tersebut kemudian mengalami sebuah kecelakaan diantaranya kemudian terpisah.Tim SAR nasional dan gabungan sukarelawan yang terdiri dari gabungan mahasiswa pencinta alam dan unsur lain akhirnya membuka

\footnotetext{
5 Lih uraian berita secara lengkap pada, Korpala UNHAS "Korpala Bantu Tuntaskan Evakuasi Korban Jatuh di Goa Dinasaurus" http://www.korpala.org/2016/05/korpala-tuntaskanevakuasi-korban-jatuh html

${ }^{6}$ Lih uraian berita secara lengkap padahttps://astacala.org/2017/09/yasta-galang-bantuanuntuk-pengungsi-bencana-alam-gunung-agung/
} 
posko dan melakukan Serch and rescue. Pencarian dilakukan selama beberapa hari, namun naas korban tidak ditemukan. Pada batas hari tertentu akhirnya SAR menutup poskonya atas pertimbangan SOP dan tidak adanya kemungkinan korban selamat. Setelah posko ditutup para mahasiswa yang tergabung di mapala ini pada akhirnya membuka posko sendiri dan melanjutkan pencarian korban. Hal itu didorong atas rasa empati terhadap keluarga korban yang sangat berharap ditemukan tubuh korban apapun keadaannya. Atas dasar empati itulah teman-teman pencinta alam tetap melakukan pencarian walaupun secara prosedur korban bukan lagi tanggungan sebuah tim SAR dan kemungkinankemungkinan korban masih bertahan hidup. Tentu peristiwa ini menunjukan bagaimana anak-anak pencinta alam tergerak bukan atas dasar prosedurprosedur standar. Mereka terkadang juga tergerak karena rasa kepedulian atas dasar kemanusiaan atau rasa empati terhadap sesama di luar tanggung jawab mereka secara formal. Mereka mau mengenyampingkan perhitungan untung rugi yang selama ini mendasari lingkungan hidup mereka yang lebih makro seperti di masyarakat era sekarang. SAR benar-benar dilakukan untuk pencarian korban yang hilang atau meninggal baik digunung maupun tempat lainnya. Operasi ini benar-benar dilakukan dengan hati yang tulus dan tanpa pamrih serta tanpa mengharapkan imbalan apapun, walaupun terkadang yang menjadi taruhanya adalah nyawa mereka sendiri. (Situmorang, 2009 :52)

Pengangkatan air di gua Bribin yang dilakukan beberapa lembaga termasuk ASC yaitu kelompok penelusur gua yang berada di Jogja juga menjadi contoh

${ }^{7}$ Lih uraian berita secara lengkap pada Asc Yogyakarta "Water For People With Energy Form Water" lainnya peran pencinta alam di masyarakat. ${ }^{7}$ Pandangan masyarakat pada umumnya tentang pencinta alam yang tidak utuh hanya melihat dari sisi negatifnya. Pandangan seperti ini membuat mereka tidak mengira bahwa selain kegiatan-kegiatan naik gunung, susur goa, panjat tebing, arung jeram, paralayang dan kegiatan outdoor lainnya juga sering melakukan kegiatan yang positif di mata masyarakat umum. Kurangnya gambaran masyarakat tentang kegiatan positif juga karena masih jarang terpublikasinya kegiatan pencinta alam sendiri. Peran pencinta alam juga menunjukan kepedulian terhadap lingkungan dengan cara pengabdian di masyarakat. Kegiatan yang dilakukan di daerah sulit terjangkau membuat anakanak pencinta alam secara tidak langsung dapat melihat kehidupan masyarakat kecil tersebut. Interaksi dengan masyarakat sekitar mendorong adanya sebuah kegiatan untuk membantu mereka sebagai rasa empati. Berkembangnya wisata di Indonesia juga menjadi bentuk salah satu peran organisasi-organisasi pencinta alam untuk membuat sebuah kegiatan pengabdian. Keahlian pencinta alam dalam teknik-teknik berpetualang dapat dimanfaatkan untuk menunjang perkembangan wisata alam tersebut. Mereka sering dimanfaatkan sebagai tenaga ahli untuk mensurvei potensipotensi yang ada disuatu wilayah tertentu. Bahkan ada beberapa daerah yang justru dikembangkan mulai dari nol oleh para penggiat alam. Seperti contoh kasus wisata arung jeram di sungai Elo dimana kegiatan pengarungan pencinta alam disana telah membuat masyarakat sekitar dilibatkan dalam kegiatan ini yang berujung pada berkembangnya wisata arung jeram di sungai Elo ini. Begitu pula 
seperti beberapa wisata gua di Gunung Kidul seperti Gua Jomblang, Kali Suci ${ }^{8}$, Pindul dan lainnya. Tentu dengan adanya wisata ini dapat membantu meningkatkan taraf ekonomi penduduk sekitar.

\section{AUTO KRITIK PENCINTA ALAM SEBAGAI CERMINAN DUNIA PEMUDA}

Berkembangnya modernisasi dan kapitalisasi tidak hanya merambah pada masyarakat umum. Pada dunia pencinta alam khususnya outdoor juga mulai tersentuh. Masuknya kapitalisasi ini mulai dari banyaknya foto-foto di media sosial hingga film di TV dan layar lebar yang menunjukan kegiatan petualangan alam bebas. Ditambah semakin berkembangnya industri mode outdoor yang menjadi tren kalangan muda. Hal ini mendorong banyaknya orang berbondong-bondong ikut bergabung dengan kegiatan outdoor tersebut. Efeknya adalah calon anggota yang ingin ikut semakin banyak namun kebanyakan hanya ingin menikmati kegiatan alam seperti di film atau media sosial. Mereka enggan untuk mengikuti aturan dan SOP yang telah ditetapkan organisasi. Pada akhirnya ada anggota yang tidak menjalankan aturan organisasi, ia hanya ikut sebatas ingin main saja. ketika sudah masuk tren inilah nilai-nilai yang sesungguhnya harus dipegang menjadi terlupakan.

Belum lagi pada kasus Mapala persoalan batas kuliah yang semakin pendek. Aturan itu membuat Mapala harus memberikan toleransi yang lebih longgar pada aturan-aturannya. Tentu hal ini menjadi tantangan tersendiri bagi Mapala, dalam artian pertentangan yang terjadi atas budaya dominan semakin kuat. Budaya counter culture mereka adalah salah satu faktor yang menumbuhkan kesadaran diri mereka. Kegiatan mereka memberikan efek sehingga benar-benar menumbuhkan kesadaran dari dirinya akan apa yang akan ia lakukan. Pada saat itu justru mereka menemukan hakekat dari kita menjadi manusia. Ketika kesadaran itu timbul pada dasarnya berarti mereka melepaskan diri dari alienasi, karena salah satu unsur alienasi adalah bahwa kita merasa asing dengan diri kita sendiri, kita kehilangan potensi kemanusian dan merasa kurang menjadi manusia (Ritzer \& Goodman, 2013:40). Ketika budaya counter culture itu melemah berarti akan semakin beresiko untuk mereka terjerat pada arus alienasi yang pada akhirnya mengikis peran mereka sebagai pemuda khususnya mahasiswa pada masyarakat luas.

Di dalam internal organisasi pun juga memiliki tantangan tersendiri kesenangan mereka pada kegiatan alam pun dapat membuat lupa hakekat dari pencinta alam sendiri, bahwa pencinta alam bukan hanya urusan bermain di alam. Nilai penting dari pencinta alam antara lain adalah mencintai alam seisinya, yang berarti meliputi semuanya. Petualangan di alam adalah sarana bukan menjadi objek pentingnya. Bagaimana kita hidup berdampingan dengan semua mahluk hidup dan biotghya secara seimbang menjadi titik utama. Kecanggihan alat, informasi, dan pengetahuan yang memungkinkan untuk semakin mudah mengakses segala petualangan disegala medan termasuk faktor yang mendorong kesenangan Mapala yang tak terbatas. Perlombaan menjadi orang pertama atau menjelajahi belahan benua lain menjadi salah satu indikator tersebut. Seakan kegiatan 
menjadi candu yang dapat membuai mereka pada keasikan mereka sendiri yang pada akhirnya berujung pada alienasi. Kegiatan konservasi pengabdian di masyarakat akan terlupakan jika hanya fokus pada keasyikan petualangan. Sehingga pencinta alam yang telah berada di kondisi itu tidak akan berbeda jauh dengan aktivitas hiburan lainnya.

Tentu semua ini bermuara bagaimana pencinta alam menghayati dan menerapkan kode etik pencinta alam sendiri. Kode etik ini jika dilaksanakan dengan baik maka anggota Mapala akan terasah secara jasmani dan rohani. Tentu juga akan berdampak pada masyarakat dimana poin empat dan lima menunjukan tanggung jawab kontribusi anggota pada masyarakat khususnya bangsa Indonesia. Aturan-aturan dan budaya pada organisasi Mapala pun juga memiliki kontribusi yang penting dimana menurut informan, dari kebiasaan-kebiasaan itu mereka merasa menjadi pribadi yang berbeda dalam artian positif. Perubahan itu dirasakan pada sikap dalam tim yang lebih toleran, adaptif pada segala kondisi, muncul jiwa kepemimpinan, perhatian dengan orang lain, kritis, dan dapat memanajemen waktu. Perubahan pada pribadi Mapala tersebut sangat menunjang untuk menjadikan ia sebagai seorang agen perubahan. Hal itu semua tentu harus diadaptasikan dengan tantangan baru dimana tantangan baru yang mereka hadapi sekarang lebih menekan mereka.

\section{KESIMPULAN}

Fenomena pencinta alam di era kita sekarang dapat menjawab keresahan tentang persoalan pemuda. Pencinta alam dapat menunjukan bagaimana stigma peran pemuda pada masyarakat secara umum masih dapat kita temui. Kode etik pencinta alam sebagai falasafah organisasi membantu penanaman nilai Mapala.
Nilai-nilai yang berkembang seperti solidaritas, toleran terhadap sesama, kepekaan pada lingkungan dan masyarakat. Nilai tersebut akhirnya dapat mendorong Mapala menjadi salah satu bagian agen perubahan. Perubahan yang dilakukan oleh Mapala terutama pada bidang konservasi dan masyarakat desa. Kontribusi mereka melalui kegiatan tidak diragukan lagi, meski dengan berjalannya kegiatan tersebut banyak yang mereka korbankan seperti kehidupan normal mahasiswa lainnya. Mereka akhirnya untuk berkegiatan tersebut harus melanggar aturan-aturan kampus seperti pada perkuliahan, disinilah kemudian muncul budaya counter culture yang berperan banyak dalam pengembangan kesadaran diri anggota dari arus alienasi yang menggerus mereka dari perannya.

Namun semakin berkembangnya waktu Mapala mempunyai tantangan yang semakin berkembang juga. Modernisasi dan kapitalis mulai menjamah seluruh bagian masyarakat termasuk pada Mapala. Mapala ditantang oleh keadaan tersebut untuk lebih adaptif dan tetap melawan hegemoni budaya dominan yang berakibat pada alienasi. Sebab ketika Mapala telah masuk ke jurang alienasi maka kode etik dapat hanya menjadi semboyan, yang pada akhirnya membuat tanggung jawab terhadap lingkungan dan rasa empati terhadap sesama akan luntur. Tentu dengan lunturnya nilai tersebut maka peran pemuda akan terkikis. Meski terdapat indikasi yang mengarah kesana namun Mapala pada hari ini masih menunjukan konsitensinya terhadap kode etik dan nilai-nilai pencinta alam.

$* * * * *$

\section{Daftar Pustaka}


Alfitri, 2007. Budaya Konsumerisme Masyarakat Perkotaan. Emperika vol.XI: 1-9.

Badil, Rudy(ed). 2005. Jejak Kampus di Jalan Alam: 40 Tahun Mapala UI. Depok: BP Mapala UI, 2005.

Badil, Rudy.2009. "Antar Hok-gie dan Idhan ke Atas", dalam Soe HokGie... Sekali Lagi, Rudy Badil, Luki Sutrisno Bekti \& Nessy Luntungan $\mathrm{R}($ ed). Jakarta: KPG, halaman 183.

Duri, Fitri Faradesa. 2015. Prilaku Penemuan Informasi (Information Seeking Behavior) Mahasiswa Pencinta Alam, sebagai Skripsi Program Studi Ilmu Informasi dan Perpustakaan, S1 Fakultas Ilmu Sosial dan Politik, UNAIR.

Fitrianingsih, Nurul. 2016. Implementasi Kode Etik Pecinta Alam Indonesia Dalam Pendidikan Islam: Studi Kasus Organisasi Mahasiswa Pecinta Alam Mitapasa Institut Agama Islam Negeri Salatiga Tahun 2016, sebagai Skripsi Program Studi Pendidikan Agama Islam, S1 Fakultas Tarbiyah dan Ilmu Keguruan, IAIN Salatiga.

Nadhiroh, Nufi Ainun. 2015. Konsep Alienasi Menurut Erich Fromm. sebagai Skripsi Sarjana Filsafat Islam, Jurusan Filsafat Agama, Fakultas Ushuluddin dan Pemikiran Islam, UIN Sunan Kalijaga Yogyakarta.

Pickles, Joana Margaret. 2000. Dari Subkultur Ke Budaya Perlawanan: Aspirasi Dan Pemikiran Sebagian Dari Kaum Punk, Hardcore dan Skinhead di Yogyakarta dan Bandung, sebagai Skripsi Program ACICIS, Fakultas Ilmu Sosial dan Politik, UMM.
Rahmadian, Gaffari. 2012. "Jejaring Sosial: Memupus Sekaligus Mengalienasi". Ranah 2:30-38.

Ritzer, George \& Douglas J. Goodman.2013.Teori Marxis dan Berbagai Ragam Teori-Teori NeoMarxian. Bantul: Kreasi Wacana.

Saputra, Hendra; Silvia Kristanti T.F, \&Sukma Noor Akbar. 2016. Pengaruh Peran Kepemimpinan Terhadap Perilaku Pro-Lingkungan Pada Anggota Organisasi Mahasiswa Pecinta Alam (Mapala) Piranha. Jurnal Ecopsy Vol 3:155159.

Schoorl. 1984. Modernisasi: Pengantar Sosiologi Pembangunan NegaraNegara Sedang Berkembang. Jakarta: PT. Gramedia.

Situmorang, Lasro Boneventura. 2009. Konsep Diri Pada Mahasiswa Mapasadha ( Mahasiswa Pencinta Alam Sanata Dharma), sebagai Skripsi Program Sarjana Psikologi, Fakultas Psikologi Universitas Sanata Dharma.

Soleh, Ady Mat. 2014. Metalhead : Studi deskriptif Gaya Hidup Pendukung Subkultur Metalhead Di Kota Surabaya. Antropologi Fisip Unair. Sumardjito. 1999. Permasalahan Perkotaan Kecenderungan Perilaku Individualis Penduduknya. Cakrawala no.3:131-135.

Arsip :

Data dari Badan Pusat Statistik Tabel "Presentase Penduduk Daerah Perkotaan Menurut Provinsi, 20102015"

Makalah Lembaga Demografi Fakultas Ekonomi UI "Grand Design dan Proyeksi Rencana Nasionla dan 


\section{Rencana Aktifitas Daerah \\ Kepemudaaan Tingkat Nasional dan Provinsi Tahun 2013.}

\section{Website :}

Amanda, Tika. 2016. Ekspedisi

Padjadjaran Nemangkawi 2016.

Diambil

dari

http://palawa.unpad.ac.id/2016/07/2

1/ekspedisi-padjadjaran-

nemangkawi-2016/.

ASC. 2013. Water for People with Energy from Water. Diambil dari http://asc.or.id/asc-jogja/water-forpeople-with-energy-from-water/.

Astacala. 2017. Yasta Galang Bantuan Untuk Pengungsi Bencana Alam Gunung Agung. Diambil dari https://astacala.org/2017/09/yastagalang-bantuan-untuk-pengungsibencana-alam-gunung-agung/.

Kalisuci Cave Tubing. 2011. Profil Kalisuci. Diambil dari http://kalisucicavetubing.blogspot.c o.id/2011/09/profil-pokdawis kalisuci.html.

Korpala. 2016. Korpala Membantu Tuntaskan Evakuasi Korban Jatuh di Gua Dinosaurus. Diambbil dari http://www.korpala.org/2016/05/ko rpala-tuntaskan-evakuasi-korbanjatuh.html .

MAPALA UI. 2017. Operasi SAR Warga Depok di Sungai Ciliwung. Diambil darihttp://mapala.ui.ac.id/2017/03/o perasi-sar-warga-depok-di-sungaiciliwung. 